\title{
INTERDISZCIPLINÁRIS ASSZOCIÁCIÓK A FÖLDÖN KÍVÜLI ÉLETFELTÉTELEK MEGTEREMTÉSE TÉMÁVAL KAPCSOLATBAN
}

\author{
Szerzők: \\ Mező Ferenc (Ph.D.) \\ Eszterházy Károly Egyetem \\ (Magyarország) \\ Mező Katalin (Ph.D.) \\ Debreceni Egyetem \\ (Magyarország) \\ Első szerző e-mail címe: \\ ferenc.mezo1@gmail.com
}

\author{
Lektorok: \\ Nemes Magdolna (Ph.D.) \\ Debreceni Egyetem \\ (Magyarország) \\ Szabóné Balogh Ágota (Ph.D.) \\ Gál Ferenc Egyetem \\ (Magyarország) \\ ...és további két anonim lektor
}

\begin{abstract}
Absztrakt
Jelen tanulmány a V. Nemzetközi Interdiszciplináris Konferencia (2020) résztvevőinek saját kutatási területük és a Földön kívüli életkörülmények megteremtésének témája közötti (esetenként távoli) asszociációit foglalja össze.
\end{abstract}

Kulcsszavak: űrkutatás, életfeltétel

Diszciplína: interdiszciplináris

\section{Abstract:}

INTERDISCIPLINARY ASSOCIATIONS RELATED TO THE TOPIC OF THE CREATION OF EXTRATERRESTRIAL LIVING CONDITIONS

The present study summarizes (sometimes remote) associative thoughts of participants of V. International Interdisciplinary Conference (2020) between their researching area and the theme of the creation of extraterrestrial living conditions.

Keywords: space exploration, living condition

Discipline: interdisciplinary

Mező Ferenc és Mező Katalin (2020). Interdiszciplináris asszociációk A földön kívüli életfeltételek megteremtése témával kapcsolatban. OxIPO - interdiszciplináris tudományos folyóirat, 2020/4, 9-21. doi: 10.35405/OXIPO.2020.4.9 
A V. Nemzetközi Interdiszciplináris Konferencia 2020. március 15-május 1. között került megrendezésre (a COVID19 vírusbetegség okozta világjárvány miatt) online formában (1. ábra).

1. ábra: az. V. Nemzetközi Interdiszciplináris Konferencia résztvevôi köre országonként, s szervezói köre intézményenként (forrás: Mezón K. és Mező P.D., 2020, 112. o.)

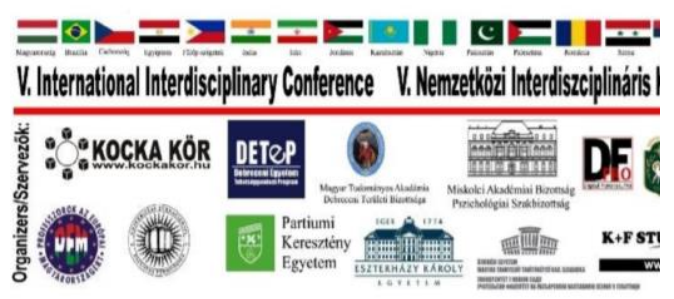

A konferencián 202 prezentációval öszszesen 274 fö vett részt. A rendezvény szervezői nyilvános kérdés formájában arra kérték a prezentációk szerzőit, hogy legalább néhány mondatban próbáljanak megválaszolni (többek között) arra a kérdésre, hogy:

„Mi a kapcsolat a prezentációjuk és Földön kivüli életfeltételek megteremtése (pl. ürhajózás, terraformálás stb.) közö̈t??"

Az interdiszciplináris asszociációk a tanulást, kutatást információfeldolgozó tevékenységnek tekintő OxIPO-modell aspektusából a következőképpen értelmezhetők: az összteljesítményt befolyásoló in- put $=$ a résztvevők kutatási témája + a szervezők által adott téma (itt: Földön kívüli életfeltételek megteremtése); process = minimálisan szükséges és elégséges a holista információfeldolgozás, a különböző témakörök közötti összefüggések megtalálása; output $=$ a beküldött asszociáció; organizáció $=$ a szándékos szervezési tevékenységek (például a válaszgyújtés módja), illetve a spontán események (például esetleges megbetegedés, internethozzáférés akadályoztatása stb.).

Meghökkentő módon mindössze csak 32 értékelhető válasz érkezett (ez a prezentációk 16\%-át, a résztvevőknek pedig kb. 11\%-át jelenti. Megjegyzés: értékelhetőnek tekintettünk a „nem tudom”, „,nincs kapcsolat", ,,-” válaszon és a válasz hiányán kívül minden választ). Ez a megfigyelt válaszszám szignifikánsan kevesebb (khi-négyzet $=14110,051, \mathrm{df}=1$, $\mathrm{p}<0,001)$ az interdiszciplináris jellegû tudományos konferencia esetében várható 99\%-os értéktől (ami 202 prezentációból 200 szerzőinek válaszát feltételezi). Az alacsony válaszszám hátterében egymást nem kizáró módon olyan okok állhatnak, mint például a járvány és vagy az internetelérés okozta problémák, érdektelenség, konferencia/e-konferencia etikettbeli tapasztalatlanság (illik részt venni a nyilvános vitában), valóban nem talált összefüggést a résztvevő a felvetett témával kapcsolatban.

Hangsúlyozandó ugyanakkor, hogy a kérdésre érkezett 32 értékelhető válasz önmagában is izgalmas asszociációkat, 
olykor egész kutatássorozatokat vázoló felvetéseket tartalmaz - demonstrálva ezzel általában az űrkutatás, szúkebb értelemben a Földön kívüli létfeltételek biztosítását célul kitűző kutatási terület lenyűgözően sokszínű világát, multi- és interdiszciplináris megközelítési lehetőségeit!

Az alábbiakban a konferencia szekciói mentén haladva mutatjuk be röviden a beérkezett válaszokat.

\section{Az „Egészség és orvostudomány” (Health and Medicine) szekció részt- vevői által adott válaszok}

Az egészségre, illetve orvostudományra koncentráló szekcióban az asszociációk egy része a lehetséges űrbalesetek megelőzésével és kezelésével volt kapcsolatban, másik része pedig a földi kutatási eredmények „nem földi” körülmények között történő megalapozására, ellenőrzésére hívta fel a figyelmet.

Baksa és tsai (2020) vizsgálatának fókuszában szén nanocsövek aggregációjának hatásai állnak a cornea regenerációja során (felvázolva egy lehetséges autóbaleset során a sérülésbe került nanoszén aggregátum hatásait): „Ezen anyag pedig nemcsak az autók fémvázas szerkezeteiben, hanem az ürhajók alkatrészeiben is megtalálhatók, így ezen esetben is érintkezhet az ember ezekkel nanorészecskékkel. Ezért is fontos a szén nanocsövek toxicitásának pontos megismerése.” (Baksa, 2020, 8. o.)

Fehér (2020) a TRPA1 ioncsatorna modulátorainak vizsgálatával összefüggés- ben utal arra, hogy mivel a jelzett ioncsatornák a Földön kívül élő, munkát végző emberekben is léteznek, a terresztriális körülmények között végzett vizsgálatok legalábbis kiinduló alapjai lehetnek az extraerresztriális körülmények között végzett kutatásoknak.

Hinnah (2020) a „TGF- $\beta$ útvonal változása Alzheimer-kórban” című vizsgálata kapcsán mutat rá arra, hogy „...egy Földön kívüli élet kialakításánál is figyelembe kéne venni, azt a valószínúleg elhanyagoltabb tényt, hogy az emberek fizikálisan igen aktívak maradjanak a szellemi képességeik megőrzése érdekében. Továbbá a kutatási eredményeink alapján szűrni lehetne az Alzheimerre hajlamos embereket már évekkel, esetleg évtizedekkel a dementia megjelenése előtt, így egy hoszszabb, akár egész életre szóló expedíció tervezésénél segítene a legalkalmasabb egyének kiválasztásában” (Hinnah, 2020, 23. о.).

A scapularis diszfunkció és a törzs-alsóvégtag stabilitásának vizsgálatára, intervenciójára fókuszált kosárlabdázók körében végzett kutatása során Lepp és Némethné (2020). Amellett, hogy a fizikai sérülések mentén is megtalálható összefüggés a téma és a Földön kívüli emberi élet témaköre között, a szerzők egy elvontabb kapcsolatra is hivatkoznak a kosárlabda szimbolikája kapcsán (Lepp és Némethné, 2020, 33. o.: „Az emberi kíváncsiság (...) mindig is jelen lesz, és rejtett szimbólumokban testesül meg, mint a kosár és a palánk." 
Újonnan szintetizált nukleozid analógok citotoxikológiai vizsgálatával összefüggésben Polyák (2020, 52. o.) megjegyzi, hogy: „Egy hatékony tumorellenes szer rendkívül hasznos lehet a terraformálás, űrhajózás közben, mivel azonnali gyógymódot nyújthat a beteg embereknek."

\section{A „Környezet” (Environment)} szekció előadói által adott válaszok

A biológiai, fizikai környezet aspektusából is érkeztek asszociációk a Földön kívüli életfeltételekkel kapcsolatban.

Firak és tsai, $(2020,18$ o.) az „X17: the search for a new particle (and how scientist at MTA Atomki may have found it)" című prezentációja kapcsán felveti, hogy: „Ahhoz, hogy egy civilizáció a bolygóján kívül is terjeszkedjen, alapvető fontosságú tudnia, hogy miként múködik a világegyetem. Ehhez járulhat hozzá egy új részecske kutatása - a nagyon távoli jövőben. Nem valószínú, hogy civilizációnk valaha is elhagyja a Naprendszert, de ha a jövőben ez sikerül, akkor elengedhetetlen annak ismerete, hogy milyen erőkre, illetve részecskékre számíthatnunk az univerzumtól."

Máté és tsai. (2020) előadásának címe „Szemes cirok (Sorghum bicolor (L.) Moench) genotípusok környezeti igényeinek összehasonlító elemzése" volt, s ennek Földön kívüli humán élettel való kapcsolatát a következők szerint fogalmazták meg: „A növényélettani folyamatok, és azok detektálásának pontos megismerése, fôleg a környezeti tényezők függvényében lehetőséget ad arra, hogy azokra olyan szintű befolyással legyünk, mely zárt rendszerű növénytermesztő rendszerben (lásd: űrállomás, űrkabin) a humán felhasználók hasznára van. A növények, életfolyamataik kismértékű stresszelése, terhelése olyan hasznos anyagok termelését válthatja ki, melyek a humán táplálkozás és egészségmegőrzés terén óriási hasznot hoz, akár Földi zárt rendszerekben, akár a jövőben gondolkodva" (Máté és tsai, 2020, 36. o.).

A száradásos repedés vizsgálata kapcsán Szatmári Roland (2020) az extraterresztriális életkörülmények biztosítása vonatkozásában egyrészt a környezeti kihívásoknak ellenállóbb anyagok kifejlesztését említi meg: másrészt rámutat, hogy: „...az űrben a nagyenergiájú részecskék kölcsönhatnak az anyaggal, mégpedig oly módon, hogy hibákat (diszlokációkat) hoznak létre benne. Ezek potenciális kiindulópontjai lehetnek egy-egy repedésnek" (Szatmári, 2020, 61. o.).

Uzonyi (2020, 68. o.) „An empirical study of Taylor's power law in random graph models and real networks" címú prezentációja kapcsán jelzi, hogy „Megvizsgálhatjuk az életkörülményeket valamely csoportban, s így megjósolhatjuk ezeket a körülményeket másokban.”

\section{A „Pedagógia, vallás és társadalom” (Pedagogy, Religion and Society) szekcióból érkezett válaszok}

Filozófiai, szorongáskezelési és drámapedagógiai összefüggések születtek a „Pe- 
dagógia, vallás és társadalom" szekcióban. Kovács Zsófia Dóra (2020, 28. o.) „Erényelméletek, avagy visszatérés Arisztotelészhez az ítélkezéselméletben" címú előadása kapcsán megjegyzi: „Prezentációm és a Földön kívüli életfeltételek megteremtése (pl. űrhajózás, terraformálás stb.) között szerintem etikai és jogi szempontból is lehet összefüggést találni. Úgy gondolom az űr minél jobbani megismerésével a már egyébként létező űrjog területén új fogalmak kidolgozására lesz szükség, melyben a jogelmélet is segítséget tud nyújtani. Hiszen valószínúleg nem lehet majd ezen új körülményekre változtatás nélkül átvinni az eddig Földön kialakított eljárásokat, gyakorlatokat.”

Sáfrány Judit (2020a, 55. o.) az iskolai környezetben megjelenő szorongásos tünetegyüttes kapcsán írja, hogy: „A Földön kívüli életfeltételek megteremtése kapcsán a szorongás értelmezése több területen is releváns. Evolúciós szempontból az ismeretlennel szembeni félelmek az egyént óvatosságra, minél szélesebb körű információszerzésre ösztönzik, ezáltal megteremtve a biztonságérzetet. Edukációs területen, tehát iskolai környezetben a tanúlók rendelkezésére álló ismeretek szükségesek ahhoz, hogy - jelen esetben a világűrről és a Földön kívüli létezésről szóló információhézagokat tudományos evidenciákkal pótoljuk. Megfelelő megalapozottságú ismeretek nélkül a fantázia végzi el a hiánypótló tevékenységet, ami gyakran vezet szorongásos reakciókhoz az új, idegen területekkel szemben". Sáfrány (2020b, 56. o.) másik prezentációjának címe „Anxiety disorders and academic achievement”, amivel összefüggésben felhívja a figyelmet arra, hogy a földön kívüli környezetben is kialakulhatnak olyan fóbiák, mint az aerofóbia, az xenofóbia és az agorafóbia.

Varga-Csikász Csenge (2020) a drámapedagógia hatástát vizsgálja a tanári kompetenciák alakulására. Kifejti, hogy (Varga-Csikász, 2020, 71. o.): „A Földön kívüli életfeltételek megteremtésével kapcsolatos témák a drámapedagógia kínálta »mintha« helyzetek megteremtésével eljátszhatók. Egy korosztálynak megfelelően kialakított gondolatkísérlet kapcsán, például Jonothan Neelands konvencióira támaszkodva és egy bizottság tagjainak szerepébe lépve, eldönthetik a résztvevők, hogy ha lehetôségünk lenne tíz különböző foglalkozású embert egy élhető bolyóra küldeni, kiket választanánk és miért - a »Theater in Education« (TIE) eszközeivel élve.

\section{A ,Tehetséggondozás és gyógype- dagógia" (Talent Development and Special Education) szekció előadói- nak asszociációi a témával kapcso- latban}

A tanulásban akadályozott (és talán tehetséges) gyermekektől a tehetséggondozó programokon át konkrét fejlesztésekig (a jövő autóiig), illetve személyekig (Rosalind Franklin) ível a szekció prezentációi és a Földön kívüli életfeltételek közötti asszocicációk sora. Fábián Fruzsina és Varga Boglárka (2020) a tanulásban akadályozott gyermekek zenei 
tehetségének vizsgálata kapcsán a két témakör egyaránt lehetetlennek tűnő volta között teremtett párhuzamot (Fábián és Varga, 2020, 16. o.): „Az emberek a földönkívüli életfeltételeket is annyira valószínűtlennek tartják, mint a tanulásban akadályozott gyermekek zenei tehetségét, de kutatásokkal és vizsgálatokkal mindkettő bebizonyítható." Varga Boglárka és Fábián Fruzsina (2020) „Tanulásban akadályozott gyermekek vizsgálata vizuális területen" címú prezentációja kapcsán pedig a vizuális kommunikáció jelentőségére irányítja a figyelmet e speciális célcsoport kapcsán.

Zsemján Eszter (2020) Szabolcs-Szatmár-Bereg Megyében a tanulásban akadályozottak integrált, inkluzív nevelésére, oktatására fókuszált prezentációjában. Témájával az integráció, inklúzió kapcsán talált párhuzamot a hosszú távú Földön kívüli tartózkodásból visszatérő asztronauták feltételezhető, várható élethelyzetével: „...az integrálás, inkluzió lenne a kapocs a Földön kívüli életfeltételekkel szemben. Ha egy űrhajós hosszú évek múltán visszatér a Földre, akkor vajon hogyan tud beilleszkedni a »megváltozott« társadalomba?".

Molnár Alexandra (2020, 46. o.) „Motiváló módszerek a tanulásban akadályozott gyermekek tanítása során" címú prezentációjhoz füződő asszociációként rámutat arra, hogy „Földön kívűl is életfeltétel lehet a tanulás, a tudás, a jó módszer alkalmazása."

Mező Ferenc (2020, 39. o.) az „Innovációs Stúdium" tehetséggondozó program bemutatása vonatkozásában jelzi, hogy: „Tekintve, hogy a Földön kívüli életfeltételek kutatása is tárgya lehet interdiszciplináris megközelítésű kutatásoknak, az Innovációs Stúdió keretein belül végzett kutatások hol szorosan, hol lazábban, de kapcsolatba hozhatók e témakörrel is."

Mező Katalin (2020, 41. o.) a „Hölgyek a tudományban" című tehetséggondozó program bemutatása kapcsán vetette fel, hogy: „A Hölgyek a tudományban programba bekapcsolódó lányok a jövő tudósai lesznek/lehetnek. Mivel igen széleskörű érdeklődést mutatatnak a természettudományok terén, így elképzelhető, hogy a földön kívüli életfeltételek megteremtésének a kutatása felé is szakosodni fognak/szakosodhatnak."

Mező Ferenc és Mező Katalin (2020, 40. o.) egy új, innovatív kognitív képességvizsgáló eszközt mutatottak be „S.M.ART - School, Measurement and Art (A new innovative measurement system of pupils' cognitive and noncognitive characteristics)" című prezentációjukban, s megjegyzik, hogy: „Függetlenül attól, hogy hol él egy tanuló, a kognitív képességekre alapvetően szükség van a tanuláshoz. A tanároknak ismerniük kell a tanulók képességeit annak érdekében, hogy garantálni lehessen a gyermekek adaptív és differenciált oktatását. A tanárok képesek lesznek használni az S.M.ART tesztet akár a Földön, akár azon kívül."

Mező Kristóf Szíriusz (2020, 42-43. o.) a jövő autóival kapcsolatban írja: „A Föl- 
dön kívüli környezet a jövő járműveinek tervezőit olyan kihívások elé állíthatja, mint például:

a) a Földinél kisebb/nagyobb gravitáció okozta problémák megoldása;

b) a légkör összetételéhez való alkalmazkodás (vagy éppen a légkör hiányának) kezelése;

c) az esetleges nyomáskülönbségekből adódó balesetek megelőzése mind a futómú, mind az utasfülke, illetve raktér tekintetében;

d) az elérhető üzemanyag és az azt felhasználni képes motor problémája,

e) a rendelkezésre álló útfelület vagy annak hiányának kezelése;

f) a földitől esetleg káros mértékben eltérő kozmikus sugárzás okozta veszély megelőzése;

g) a jármű mozgásszabadságának változásából (például: új repülés, merülés funkciókból) adódó technológia fejlesztése;

h) a karosszéria alkalmazkodása a nem földi körülményekhez (például esetleges légkör nélküli környezetben - mondjuk a Holdon - nem szükséges az áramvonalasságra törekedni);

i) utasbiztonság megszokottól eltérő feltételeinek biztosítása; stb.

Szakács Erika Tünde (2020, 60. o.) Rosalind Franklin életét, tudományos munkásságát vázolta, s megjegyezte, hogy: „A prezentációmban bemutatott kutató nő, talán ha lehetősége nyílt volna rá megváltoztatta volna a DNS-t, úgy hogy egy másik földön, megteremtett környezetben is életképes legyen."

\section{A „Mesterséges intelligencia és in- formatikai kultúra" (Artificial Intelli- gence and IT Culture) szekcióbeli előadók kapcsolódása a témához}

E szekcióban egyrészt az űrbéli tartózkodásra, illetve e tartózkodást segítő mesterséges intelligenciával való együttműködésre felkészítő szoftverekre, valamint az extraterresztriális hulladékgazdálkodásra irányultak az asszociációk.

Csukonyi és Papp (2020) „Sportpszichológus vagy esportpszichológus? A sportpszichológia szerepe az e-sportban" címú munkájuk kapcsán felvetették, hogy: „Az e-sportban szerzett képességek és készségek elősegíthetik a mesterséges intelligenciát alkalmazó eszközök és magával a mesterséges intelligenciával rendelkező, emberrel való kapcsolattartásra kifejlesztett robotokkal, úgynevezett »kobotokkal« való sikeres együttmúködést” (Csukonyi és Papp, 2020, 14. o.).

„Egy letűnt műfaj újjáéledése - A klaszszikus szerepjáték műfaji konvencióinak alakulása a kétezres években" volt a címe Krek (2020, 30. o.) prezentációjának, aki megjegyzi, hogy: „...számos olyan videojáték létezik, amelyik igyekszik egy szimulált környezetben" foglalkozni a Földön kívüli életkörülmények témájával.

Roskó Tibor (2020, 54. o.) hulladékgazdálkodással (is) foglalkozó mesterséges intelligencia fejlesztéseket mutatott be három év távlatában, s megjegyezte, hogy: „Hulladék az ürben is keletkezik, annak kezelése talán még nagyobb kihívás, mint a Földön”. 
A „Művészet és történelem” (Art and History) szekció előadói által adott válaszok

A szekcióban született asszociációk egyrészt a művészetek univerzális (földi és űrbéli körülmények között is alkalmazható) jellegére, másrészt a világűr művészeti teljesítményeket facilitáló hatására utalnak.

Lengyel (2020, 31. o.) a „Prelüd műfajának kiteljesedése marimba darabokban" című prezentációja kapcsán jelzi, hogy: „Prelüdök abszolút megvalósíthatók a Földön kívüli életben is."

Mátyus (2020, 37. o.) a mese és a gyermeki lélek vonatkozásában megjegyzi: „A gyermektől a mesék olyan fantáziát és kreativitást kívánnak meg amelyek szükségesek a „Földön kívüli” absztrakciók elképzeléséhez".

Mező Péter Dániel (2020, 45. o.) „Zrínyi Miklós: Szigeti veszedelem" című előadása kapcsán írja, hogy „A prezentáció végén kifejtett gondolat azt boncolgatja, hogy mennyire jelentősek napjainkban a régebben íródott művek, avagy mennyire fontos a múlt ismerete a jövő építéséhez. Mivel a jövő a világegyetem benépesítése felé tart, érdemes ezen elgondolkodni. Másrészt: izgalmas kísérlet lehet a múlt irodalmi alkotásait Földön kívüli környezetbe adaptálni a kortárs olvasó-, nézőközönség érdeklődésének felkeltése céljából.

„A prométheuszi magatartás camus-i értelmezése" címet adta Pavlovics Zsófia (2020, 50. o.) prezentációjának, amivel kapcsolatban szól arról, hogy: „Ahogyan a mítoszoknak sokan meseszerű jelleget tulajdonítanak és irodalmi múvek, esetleg filmek alapját képezik, ugyanígy a Földön kívüli élet is gyakran témája könyveknek, filmeknek, például sci-fi jellegú alkotásoknak. Mitológiai témájú filmek például az Oidipus király, Trójai nők, Trója. A Földön kívüli élet szintén népszerű témája a filmeknek: Apollo 18, Érkezés, Csillagkapu".

Tóth Lilla (2020) „Megragadható pillanatok az impressziók hullámaiban" címmel adta közre gondolatait a konferencián. Meglátása szerint (Tóth, 2020, 67.o.): „A Földünk természetét megragadó impresszionizmus betekintést nyújt itteni életünk kincseibe. Lényege a pillanat megragadása, hiszen mindez elszáll, nem tér vissza. Ezen hasonlat segítségével megközelítve a Földön kívüli kutatásokat, beleláthatunk abba, hogy más bolygókon jelenlegi körülményeink nem alkothatók újra, hiszen minden bolygó egyedi életfeltételekkel bír. A Földön túli ismeretlen misztikuma kíváncsiságunkat táplálhatja, a művészethez hasonlóan millió kiaknázatlan területe vár még felfedezésre."

\section{A „Család, közösség, jog és} gazdaság” (Family, Community, Law and Economy) szekció előadóinak reflexiói

Mindössze két szerző közölt értékelhető asszociációkat a Földön kívüli életkörülmények megteremtése témával kapcsolatban. Ezek az asszociációk ugyanakkor 
igen gyakorlatias megfontolásokat ajánlanak figyelmünkbe.

Mező Lilla Dóra (2020, 44. o.) a ghánai nők helyzetét vázoló „Változnak az idők” címú prezentációja kapcsán arra hívja fel a figyelmet, hogy: „Egyrészt az űrkutatás tanulhat a földi (olykor mostoha) természeti körülmények közötti építészeti, létfeltétel biztosítást nyújtó megoldásokból, másrészt a terraformálás tapasztalatai révén a Föld is lakhatóbb lehet a jövőben.”

Németh János (2020, 48. o.) „Szankció a jobb jövőért? - A jóvátételi munka célja és tapasztalatai a hazai büntetéskiszabásban" témával kapcsolatban jegyezte meg, hogy: „A prezentációm nem kapcsolódik a kérdéses témakörhöz, mindazonáltal maga a büntetőjog, valamint a büntetéskiszabás - melynek körébe tartozik kutatásom is -, kétségkívül elengedhetetlen, mint szükséges eszköz egy Földön kívüli társadalom fenntartásához. Büntető igazságszolgáltatásra - sajnos csak olyan idealizált világokban nincs szükség, ahol például a kis népességszám, az egyes emberek közötti nagy távolságok miatt nincs alkalom a bűnre, s így bűnözés sincs (Isaac Asimov: A mezítelen nap)".

\section{Zárógondolat}

A „Mi a kapcsolat a prezentációjuk és Földön kívüli életfeltételek megteremtése (pl. űrhajózás, terraformálás stb.) között?” kérdésre kisszámú, ám igen sokszínú, további kutatási lehetőségeket körvonala- zó válasz született az V. Nemzetközi Interdiszciplináris Konferencia során.

Tudománysegítést előtérbe helyező szervezői szempontból a konferenciasorozat jövőbeli alkalmai során fokozott figyelmet kell fordítani a résztvevők motiválására, minél több lehetőséget szükséges adni a multi- és interdiszciplináris gondolkodásra, illetve a konferencia kapcsán kialakítható kutatói együttmúködések elősegítésére.

\section{Irodalom}

Baksa V., Ujlaki E., Tóth D.A. és SzigetiTuráni M. (2020): Szén nanocsövek aggregációjának hatásai a cornea regenerációja során In: Mező F. (szerk.): V. Nemzetközi Interdiszciplináris Konferencia: Nyilvános kérdések és válaszok gyüjteménye. Letöltés: 2020.04.23. Web: https://drive.google.com/file/d/1xqr gPzC9ux

Csukonyi Cs. és Papp D. (2020): Sportpszichológus vagy e-sportpszichológus? - A sportpszichológia szerepe az esportban In: Mező F. (szerk.): $V$. Nemzetkëzi Interdiszciplináris Konferencia: Nyilvános kérdések és válaszok gyüjteménye.Letöltés:2020.04.23. Web:

https://drive.google.com/file/d/1xqr gPzC9uxoX7DNK71IEOUC3MyZBAP2/view

Fábián F. és Varga B. (2020): Tanulásban akadályozott gyermekek vizsgálata zenei területen In: Mező F. (szerk.): $V$. Nemzetközi Interdiszciplináris Konferencia: 
Nyilvános kérdések és válaszok gyüjteménye. Letöltés: 2020.04.23. Web: https://drive.google.com/file/d/1xqr gPzC9uxoX7DNK71IEOUC3My$\mathrm{ZBAP} 2 /$ view

Fehér Á. (2020): TRPA1 ioncsatorna modulátorainak vizsgálata In: Mező F. (szerk.): V. Nemzetközi Interdiszciplináris Konferencia: Nyilvános kérdések és válaszok gyüjteménye. Letöltés: 2020.04.23. Web:

https://drive.google.com/file/d/1xqr gPzC9uxoX7DNK71IEOUC3MyZBAP2/view

Firak, D. S., Krasznahorkay, A.J., Csatlós, M., Csige, L., Gulyás, J., Koszta, M., Szihalmi, B., Timár, J., Nagy, Á., Sas, N.J. and Krasznahorkay, A. (2020): X17: the search for a new particle (and how scientist at MTA Atomki may have found it) In: Mező F. (szerk.): $V$. Nemzetközi Interdiszciplináris Konferencia: Nyilvános kérdések és válaszok gyüteménye. Letöltés: 2020.04.23. Web: https://drive.google.com/file/d/1xqr gPzC9uxoX7DNK71IEOUC3MyZBAP2/view

Hinnah B. (2020): TGF- $\beta$ útvonal változása Alzheimer-kórban In: Mező F. (szerk.): V. Nemzetközi Interdiszciplináris Konferencia: Nyilvános kérdések és válaszok gyüjteménye. Letöltés: 2020.04.23. Web:

https://drive.google.com/file/d/1xqr gPzC9uxoX7DNK71IEOUC3MyZBAP2/view
Kovács Zs. D. (2020): Erényelméletek, avagy visszatérés Arisztotelészhez az ítélkezéselméletben In: Mező F. (szerk.): V. Nemzetközi Interdiszciplináris Konferencia: Nyilvános kérdések és válaszok gyüjteménye.Letöltés:2020.04.23. Web: https://drive.google.com/file/d/1xqr gPzC9uxoX7DNK71IEOUC3MyZBAP2/view

Krek N. (2020): Egy letűnt műfaj újjáledése - A klasszikus szerepjáték múfaji konvencióinak alakulása a kétezres években In: Mező F. (szerk.): V. Nemzetközi Interdiszciplináris Konferencia: Nyilvános kérdések és válaszok gyüjteménye. Letöltés: 2020.04.23. Web: https://drive.google.com/file/d/1xqr gPzC9uxoX7DNK71IEOUC3MyZBAP2/view

Lengyel E. (2020): Prelüd múfajának kiteljesedése marimba darabokban In: Mező F. (szerk.): V. Nemzetközi Interdiszciplináris Konferencia: Nyílvános kérdések és válaszok gyüiteménye. Letöltés: 2020.04.23. Web: https://drive.google.com/file/d/1xqr gPzC9uxoX7DNK71IEOUC3MyZBAP2/view

Lepp K. és Némethné Gyurcsik Zs. (2020): Scapularis diszfunkció és a törzs-alsóvégtag stabilitásának vizsgálata, intervenciója a kosárlabdázók körében In: Mező F. (szerk.): $V$. Nemzetközi Interdiszciplináris Konferencia: Nyilvános kérdések és válaszok gyüjteménye. Letöltés: 2020.04.23. Web: 
https://drive.google.com/file/d/1xqr gPzC9uxoX7DNK71IEOUC3MyZBAP2/view

Máté Á., Murányi E., Zsembeli J. és Veres Sz. (2020): Szemes cirok (Sorghum bicolor (L.) Moench) genotípusok környezeti igényeinek összehasonlító elemzése In: Mező F. (szerk.): $V$. Nemzetközi Interdiszciplináris Konferencia: Nyilvános kérdések és válaszok gyüjteménye. Letöltés: 2020.04.23. Web: https://drive.google.com/file/d/1xqr gPzC9uxoX7DNK71IEOUC3MyZBAP2/view

Mátyus M. (2020): „Kettős tükör”: A mese és a gyermeki lélek In: Mező F. (szerk.): V. Nemzetközi Interdiszciplináris Konferencia: Nyilvános kérdések és válaszok gyüjteménye. Letöltés: 2020.04.23. Web:

https://drive.google.com/file/d/1xqr gPzC9uxoX7DNK71IEOUC3MyZBAP2/view

Mezô F. (2020): Innovációs Stúdium In: Mező F. (szerk.): V. Nemzetközi Interdiszciplináris Konferencia: Nyílvános kérdések és válaszok gyüjteménye. Letöltés: 2020.04.23.

Web:

https://drive.google.com/file/d/1xqr gPzC9uxoX7DNK71IEOUC3MyZBAP2/view

Mező F. és Mező K. (2020): S.M.ART School, Measurement and Art (A new innovative measurement system of pupils' cognitive and non-cognitive characteristics) In: Mező F. (szerk.): V. Nemzetközi Interdiszciplináris Kon- ferencia: Nyilvános kérdések és válaszok gyüjteménye. Letöltés:2020.04.23. Web: https://drive.google.com/file/d/1xqr gPzC9uxoX7DNK71IEOUC3MyZBAP2/view

Mező K. (2020): Hölgyek a tudományban In: Mező F. (szerk.): V. Nemzetközi Interdiszciplináris Konferencia: Nyílvános kérdések és válaszok gyüjte-ménye. Letöltés: 2020.04.23. Web: https://drive.google.com/file/d/1xqr gPzC9uxoX7DNK71IEOUC3MyZBAP2/view

Mező K. és Mező P. D. (2020): Az V. Nemzetközi Interdiszciplináris Konferencia a hadviselést, lélektani hadviselést is érintette. Lélektan és hadviselés interdiszciplináris folyoirat, II. évf. 2020/1. szám. 111-112.

Mező K. Sz. (2020): A jövő autói In: Mező F. (szerk.): V. Nemzetközi Interdiszciplináris Konferencia: Nyilvános kérdések és válaszok gyüjteménye. Letöltés: 2020.04.23. Web: https://drive.google.com/file/d/1xqr gPzC9uxoX7DNK71IEOUC3MyZBAP2/view

Mező L. D. (2020): „Változnak az idők”: a nők helyzete Ghánában In: Mező F. (szerk.): $V$. Nemzetközi Interdiszciplináris Konferencia: Nyilvános kérdések és válaszok gyüjteménye. Letöltés: 2020.04.23. Web: https://drive.google.com/file/d/1xqr gPzC9uxoX7DNK71IEOUC3MyZBAP2/view 
Mező P. D. (2020): Zrínyi Miklós: Szigeti veszedelem In: Mezô F. (szerk.): $V$. Nemzetközi Interdiszciplináris Konferencia: Nyilvános kérdések és válaszok gyüjteménye. Letöltés: 2020.04.23. Web: https://drive.google.com/file/d/1xqr gPzC9uxoX7DNK71IEOUC3MyZBAP2/view

Molnár A. (2020): Motiváló módszerek a tanulásban akadályozott gyermekek tanítása során In: Mező F. (szerk.): $V$. Nemzetközi Interdiszciplináris Konferencia: Nyilvános kérdések és válaszok gyüteménye. Letöltés: 2020.04.23. Web: https://drive.google.com/file/d/1xqr gPzC9uxoX7DNK71IEOUC3My$\mathrm{ZBAP} 2 /$ view

Németh J. (2020): Szankció a jobb jövőért? - A jóvátételi munka célja és tapasztalatai a hazai büntetéskiszabásban In: Mező F. (szerk.): V. Nemzetközi Interdiszciplináris Konferencia: Nyílvános kérdések és válaszok gyüjteménye. Letöltés: 2020.04.23. Web: https://drive.google.com/file/d/1xqr gPzC9uxoX7DNK71IEOUC3MyZBAP2/view

Pavlovics Zs. (2020): A prométheuszi magatartás camus-i értelmezése In: Mező F. (szerk.): V. Nemzetközi Interdiszciplináris Konferencia: Nyilvános kérdések és válaszok gyüjteménye. Letöltés: 2020.04.23. Web: https://drive.google.com/file/d/1xqr gPzC9uxoX7DNK71IEOUC3MyZBAP2/view
Polyák L. (2020): Újonnan szintetizált nukleozid analógok citotoxikológiai vizsgálata In: Mező F. (szerk.): $V$. Nemzetközi Interdiszciplináris Konferencia: Nyilvános kérdések és válaszok gyüteménye. Letöltés: 2020.04.23. Web: https://drive.google.com/file/d/1xqr gPzC9uxoX7DNK71IEOUC3MyZBAP2/view

Roskó T. (2020): Mesterséges intelligencia fejlesztések három év távlatában In: Mező F. (szerk.): V. Nemzetközi Interdiszciplináris Konferencia: Nyílvános kérdések és válaszok gyüjteménye. Letöltés: 2020.04.23.

Web: https://drive.google.com/file/d/1xqr gPzC9uxoX7DNK71IEOUC3MyZBAP2/view

Sáfrány J. (2020a): Szorongásos tünetegyüttes az iskolai környezetben In: Mező F. (szerk.): V. Nemzetközi Interdiszciplináris Konferencia: Nyilvános kérdések és válaszok gyüiteménye. Letöltés: 2020.04.23. Web: https://drive.google.com/file/d/1xqr gPzC9uxoX7DNK71IEOUC3MyZBAP2/view

Sáfrány, J. (2020b): Anxiety disorders and academic achievement In: Mező F. (szerk.): V. Nemzetközi Interdiszciplináris Konferencia: Nyilvános kérdések és válaszok gyüjteménye. Letöltés: 2020.04.23. Web: https://drive.google.com/file/d/1xqr gPzC9uxoX7DNK71IEOUC3MyZBAP2/view 
Szakács E. T. (2020): Rosalind Franklin In: Mező F. (szerk.): V. Nemzetközi Interdiszciplináris Konferencia: Nyílvános kérdések és válaszok gyüjteménye. Letöltés: 2020.04.23.

Web: https://drive.google.com/file/d/1xqr gPzC9uxoX7DNK71IEOUC3MyZBAP2/view

Szatmári R. (2020): Száradásos repedezés vizsgálata In: Mező F. (szerk.): $V$. Nemzetközi Interdiszciplináris Konferencia: Nyilvános kérdések és válaszok gyüjteménye. Letöltés: 2020.04.23. Web: https://drive.google.com/file/d/1xqr gPzC9uxoX7DNK71IEOUC3MyZBAP2/view

Tóth L. (2020): Megragadható pillanatok az impressziók hullámaiban In: Mező F. (szerk.): V. Nemzetközi Interdiszciplináris Konferencia: Nyilvános kérdések és válaszok gyüjteménye. Letöltés: 2020.04.23. Web: https://drive.google.com/file/d/1xqr gPzC9uxoX7DNK71IEOUC3MyZBAP2/view

Uzonyi N. (2020): An empirical study of Taylor's power law in random graph models and real networks In: Mező F. (szerk.): V. Nemzetköz̨i Interdiszciplináris Konferencia: Nyilvános kérdések és válaszok gyüjteménye. Letöltés: 2020.04.23. Web:
https://drive.google.com/file/d/1xqrgPz C9uxoX7DNK71IEOUC3MyZBAP2/view

Varga B. és Fábián F. (2020): Tanulásban akadályozott gyermekek vizsgálata vizuális területen In: Mező F. (szerk.): V. Nemzetközi Interdiszciplináris Konferencia: Nyilvános kérdések és válaszok gyüiteménye. Letöltés: 2020.04.23. Web: https://drive.google.com/file/d/1xqr gPzC9uxoX7DNK71IEOUC3MyZBAP2/view

Varga-Csikász Cs. (2020): A drámapedagógia hatása a tanári kompetenciák alakulására In: Mező F. (szerk.): $V$. Nemzetközi Interdiszciplináris Konferencia: Nyilvános kérdések és válaszok gyüteménye. Letöltés: 2020.04.23. Web: https://drive.google.com/file/d/1xqr gPzC9uxoX7DNK71IEOUC3MyZBAP2/view

Zsemján E. (2020): A tanulásban akadályozottak integrált, inkluzív nevelése, oktatása Szabolcs-Szatmár-Bereg Megyében. In: Mező Ferenc (szerk.): $V$. Nemzetközi Interdiszciplináris Konferencia: Nyilvános kérdések és válaszok gyüjteménye. Letöltés: 2020.04.23. Web: https://drive.google.com/file/d/1xqr gPzC9uxoX7DNK71IEOUC3MyZBAP2/view 